\title{
JUDICIAL INTERPRETATION IN RESOLVING CONFLICT ON JURISDICTION BETWEEN THE CENTRAL GOVERNMENT AND THE FEDERATING UNITS:
}

THE POLITICS OF SPACE, THE PSYCHOLOGY OF JUDGING AND THE PRINCIPLES OF KEYNESIAN FEDERALISM*

\begin{abstract}
The tension between the central government and the federating units has always been an intractable issue between the forces of centralization and decentralization in a federalism with the judiciary at the intersection of the conflict. Therefore, this study examines judicial interpretation in resolving conflict on jurisdiction between the central government and the federating units. It applies Henri Lefebvre's theory of space, Richard Ford's analysis of jurisdiction, Benjamin Cardozo's and Oliver Wendell Holmes's psychology of judging to judicial interpretation in resolving conflict on jurisdiction between the central government and the federating units. It finds that the justices on the majority and the minority who interpret the constitution to resolve questions of jurisdiction between the central government and the federating units often play politics of space hidden within the interstices of legal rules without being conscious of their psychological biases. Hence, it argues that instead of playing politics of space, what the justices should do is to apply the principles in Keynesian federalism bolstered by the rule of presumption. With this, the influence of politics borne of psychological biases can be reduced while both the central government and the federating units are given equal chances. In conclusion, it recommends that whenever the judges are called upon to resolve conflict between the central government and the
\end{abstract}

*Muyiwa Adigun; PhD, Senior Lecturer University of Ibadan. Contact: muyiwa.adigun@gmail.com. 
federating units, the principle in Keynesian federalism with the rule of presumption should be applied.

Keywords: Federalism, Henri Lefebvre, Richard Ford, Benjamin Cardozo, Oliver Wendell Holmes, Keynes, Presumption, Judicial Interpretation

\section{Résumé}

La tension entre le gouvernement central et les unités fédérées permet d'expliquer les forces de centralisation et de décentralisation au sein du fédéralisme. Quant au pouvoir judiciaire, il se situe à l'intersection de cette tension. Cet article examine donc l'interprétation judiciaire lors de résolutions de conflits de compétence entre le gouvernement central et les unités fédérées. Pour ce faire, il applique la théorie de l'espace d'Henri Lefebvre, l'analyse de la compétence de Richard Ford ainsi que la psychologie du jugement dans la résolution de conflits de compétence de Benjamin Cardozo et d'Oliver Wendell Holmes. Cet article propose que les juges majoritaires et minoritaires interprétant la constitution sur des questions de compétence opèrent dans des espaces non visibles situés à l'interstice des règles juridiques, et ce, sans être conscients de leurs propres biais psychologiques. Par conséquent, cette analyse soutient que plutôt que de participer à des joutes politiques au cœur de ces espaces cachés, les juges devraient appliquer le principe du fédéralisme keynésien soutenu par la règle de la présomption. Ainsi, l'influence de la politique fondée sur des biais cognitifs peut être réduite donnant ainsi au gouvernement central et aux unités fédérées des chances égales. En conclusion, cet article soutient que chaque fois que les juges sont appelés à résoudre un conflit entre le gouvernement central et les unités fédérées, le principe du fédéralisme keynésien et la règle de présomption devraient être appliqués. 
Mots-clés : Fédéralisme, Henri Lefebvre, Richard Ford, Benjamin Cardozo, Oliver Wendell Holmes, Keynes, présomption, interprétation judiciaire.

\section{INTRODUCTION}

Federalism as a concept suggests that there are at least two forms of government with each operating in its own sphere on the basis of shared powers. One of the two forms of government is known as the central (or federal) government while the other one is known as the constituent or federating units. ${ }^{1}$ The basis upon which power is shared is that certain powers belong to the central government while others belong to the constituent units. The underlying principle for sharing is known as the principle of centralization and non-centralization. ${ }^{2}$ What this principle implies is that the powers that belong to the central government cannot be taken from it and at the same time the powers that belong to the constituent units can also not be taken from them. ${ }^{3}$

${ }^{1}$ On federalism, see generally KC Wheare, Federal Government (4th edn, Oxford University Press 1967); Anand Menon and Martin A Schain (eds), Comparative Federalism: The European Union and the United States in Comparative Perspective (Oxford University Press 2006); Soren Dosenrode, 'Federalism' in Soren Dosenrode (ed), Approaching the EUropean Federation? (Ashgate Publishing Ltd 2007) 7-37. 2 Eghosa Emmanuel Osaghae, 'What Man Has Joined Together: Ethnicity, Federalism and State Politics' An Inaugural Lecture delivered at the University of Ibadan, Thursday 22 August 2019, 11.

3 Eghosa E Osaghae, 'A Reassessment of Federalism as a Degree of Decentralization' (1990) 20(1) Publius: The Journal of Federalism 83-98; Ronald L Watts, 'Federalism, Federal Systems, and Federations' (1998) 1 Annual Review of Political Science 117-137. This principle tends to distinguish federalism from decentralization. In decentralization, there is an absolute authority that gives power to the constituent units as it wishes and could take at will; whereas there is no such authority in a federalism. Federalism in this context is legal-constitutional. The division of powers is written in a constitution. See Osaghae (n 2) 11. Federalism can also be seen as a solution. In this respect, it takes the form of various arrangements manifesting as consociationalism, proportionality, decentralization/devolution, regionalization, local autonomy, redressive and remedial policies etc. See Osaghae (n 2) 11. See also F Palermo and K Kössler, Comparative Federalism: Constitutional 
Federalism has been considered the most ingenious means of managing diversity ${ }^{4}$ which may be ethnic, ${ }^{5}$ cultural, ${ }^{6}$ religious, territorial7 or economic. ${ }^{8}$ Examples of federal regimes are Australia, Austria, Belgium, Canada, Comoros, Ethiopia, Germany, India, Italy, Malaysia, Nigeria, Spain, Switzerland, Tanzania, and the United States of America. In managing diversity, the judiciary is sometimes called upon to settle disputes between the central government and the federating units with respect to their respective sphere of operation. In this study, it is argued that whenever the judiciary is invited to settle a dispute between the central government and the federating units with respect to the question of who is competent to regulate a particular field, the judges are often unconsciously involved in politics of space manifesting as ideological bias between supporters of centralization and those of decentralization. It is further argued that this ideological bias is hidden within the interstices of legal rules whenever they are sufficiently broad to accommodate diametrically opposed

Arrangements and Case Law (Hart Publishing 2017) 281-315; Michael Keating and Guy Laforest, Constitutional Politics and the Territorial Question in Canada and the United Kingdom: Federalism and Devolution Compared (Palgrave Macmillan 2018); Daniel Halberstam and Mathias Reimann (eds), Federalism and Legal Unification: A Comparative Empirical Investigation of Twenty Systems (Springer 2014); Núria Bosch and José M Durán (eds), Fiscal Federalism and Political Decentralization: Lessons from Spain, Germany and Canada (Edward Elgar Publishing Limited 2008).

4 Osaghae (n 2) 11.

5 See Michael G Breen, 'The Origins of Holding-Together Federalism: Nepal, Myanmar, and Sri Lanka' (2018) 48(1) Publius: The Journal of Federalism 26-50; Katharine Adeney, Federalism and Ethnic Conflict Regulation in India and Pakistan (Palgrave Macmillan 2007); Yonatan Tesfaye Fessha, Ethnic Diversity and Federalism: Constitution Making in South Africa and Ethiopia (Ashgate Publishing Ltd 2010) 25-61.

6 Wayne Norman, Negotiating Nationalism: Nation-Building, Federalism, and Secession in the Multinational State (Oxford University Press 2006) 73-92.

${ }_{7}$ See Wilfried Swenden, 'Governing Diversity in South Asia: Explaining Divergent Pathways in India and Pakistan’ (2018) 48(1) Publius: The Journal of Federalism 102-133.

8 Richard Simeon, 'Constitutional Design and Change in Federal Systems: Issues and Questions' (2009) 39(2) Publius: The Journal of Federalism 241-261, 242. 
views. However, to reduce the influence of ideology as politics of space, it is submitted that the principles of Keynesian federalism supported by the doctrine of presumptions should be adopted.

In order to investigate the issue of politics of space, the theories of Henri Lefebvre, ${ }^{9} \mathrm{a}$ French philosopher, and Richard Thompson Ford, an American critical race theorist ${ }^{10}$ are considered most relevant. Although, Henri Lefebvre thoroughly engaged with the question of how space is constructed, he did not address the issue from a legal perspective, whereas, Richard Ford interrogated the legal dimension of the same issue. Also, since the argument is that judges are unconsciously involved in politics of space, it is considered imperative that the psychological process involved in judging should be interrogated to understand politics of

9 On the works of Henri Lefebvre, see Henri Lefebvre, The Survival of Capitalism: Reproduction of the Relations of Production (Frank Bryant tr, St Martin's Press 1976); Henri Lefebvre, The Sociology of Marx (Norbert Guterman tr, Columbia University Press 1982); Henri Lefebvre, The Production of Space (Donald Nicholson-Smith tr, Basil Blackwell 1991); Henri Lefebvre, Writings on Cities Eleonore Kofman and Elizabeth Lebas tr, Basil Blackwell 1996); Henri Lefebvre, Critique of Everyday Life: Foundations for a Sociology of Everyday vol II (John Moore tr, Verso 2002); Henri Lefebvre, The Urban Revolution (Robert Bononno tr, University of Minnesota Press 2003); Henri Lefebvre, Rhythmanalysis: Space, Time and Everyday (Stuart Elden and Gerald Moore tr, Continuum 2004); Henri Lefebvre, Dialectical Materialism (John Sturrock tr, University of Minnesota 2009); Henri Lefebvre, State, Space, World (Neil Brenner and Stuart Elden eds; Gerald Moore, Neil Brenner, and Stuart Elden tr; University of Minnesota 2009).

${ }^{10}$ On the works of Richard Ford, see Richard Thompson Ford, 'The Boundaries of Race: Political Geography in Legal Analysis' (1994) 107(8) Harvard Law Review 1841; Richard T Ford, 'Law's Territory (A History of Jurisdiction)' (1999) 97(4) Michigan Law Review 843; Richard T Ford, 'Law's Territory (A History of Jurisdiction)' in Nicholas Blomley, David Delaney and Richard T Ford (eds), The Legal Geographies Reader: Law, Power and Space (Blackwell 2001) 200-217; Richard Thompson Ford, 'Law and Borders' (2012) 64(1) Alabama Law Review 123; Richard Ford, 'Against Cyberspace' in Austin Sarat, Lawrence Douglas and Martha Merrill Umphrey (eds), The Place of Law (The University of Michigan Press 2003) 147-180. 
space. For this interrogation, the reflections of Benjamin Cardozo ${ }^{11}$ and Oliver Wendell Holmes ${ }^{12}$ are considered most relevant.

This study is divided into six parts. The first part introduces the study. The second part discusses the writings of Henri Lefebvre and Richard Ford on the politics of space. The third part discusses the reflections of Benjamin Cardozo and Oliver Wendell Holmes on the nature of judicial process. The fourth part discusses politics of space in jurisdictional disputes and places it within the context of psychology of judging. The fifth part discusses the relevance of Keynesian federalism. The sixth part concludes the study.

\section{PART 1. THE POLITICS OF SPACE}

The politics of space is concerned with space as a neutral territory and what is erected on it as being laden with ideology. Henri Lefebvre views space from these two perspectives. The first one is that space is a territory on which nothing is erected. It can be likened to an empty container. From this perspective, space appears neutral and innocent. The second perspective is that things could be erected on space. If space is empty like a container, what is erected on it is like a content. ${ }^{13}$ While space as a territory is innocent or neutral, its content is not. Indeed, it is ideological and brings about the 'politics of space'. ${ }^{14}$ On the surface, when one looks at space and what is erected on it, space appears indifferent. However, the truth of the matter is that it has never been indifferent. The reason why it appears indifferent is because one does not know the history of how the present structure erected on it came into existence. ${ }^{15}$ Space as

\footnotetext{
${ }^{11}$ Benjamin N Cardozo, The Nature of the Judicial Process (Yale University Press 1921).

12 Oliver Wendell Holmes, 'The Path of the Law' (1997) 110(5) Harvard Law Review 991-1009.

${ }_{13}$ Lefebvre, State, Space, World (n 9) 168-70; Lefebvre, The Production of Space (n 9) 94, 101, 360.

${ }^{14}$ Lefebvre, The Production of Space (n 9) 60.

${ }^{15}$ Lefebvre, The Urban Revolution (n 9) 23-44.
} 
it is at present is a reflection of how things were done in the past with a particular goal in mind. It is a product of history shaped by politics even though it appears as if nothing had happened. ${ }^{16}$ Therefore, space is a social product and can be made use of the same way as a physical object. ${ }^{17}$ In a nutshell, 'there is a politics of space because space is political. ${ }^{\prime} 8$ Decisions about the private and the collectives, ${ }^{19}$ centralization and decentralization ${ }^{20}$ and the conflict engendered in a national polity are all politics of space.

Richard Ford, like Henri Lefebvre, conceives space as having two dimensions. In the technical language of the law, space is known as jurisdiction. The two dimensions of jurisdiction are territory and social practice. ${ }^{21}$ Jurisdiction as a territory is real as a matter of fact because it can be touched. ${ }^{22}$ Territory is like an empty vessel and it is on it that the power of government is exercised. ${ }^{23}$ It is also like a container in which there are individuals and resources. ${ }^{24}$ Jurisdiction as social practice is about people's interaction with one another. It is how people relate with one another that gives meaning to real or physical territory even though people tend to think it is otherwise. How people treat or regard land and the value they place on it depend on their interaction with one another. Although, territorial space may sometimes precede social practice, it does not change the fact that social practice confers meaning on territorial space. Social practice is enforced by social custom and law. ${ }^{25}$

${ }^{16}$ Lefebvre, State, Space, World (n 9) 170-171; Lefebvre, The Urban Revolution (n 9) 157; Lefebvre, Writings on Cities (n 9) 97-99.

17 Lefebvre, State, Space, World (n 9) 171; Lefebvre, The Urban Revolution (n 9) 154-155.

${ }_{18}^{18}$ Lefebvre, State, Space, World (n 9) 174.

19 Ibid 181.

${ }^{20}$ Ibid 179.

${ }^{21}$ Richard T Ford, 'Law's Territory (A History of Jurisdiction)' (1999) 97(4) Michigan Law Review 843.

${ }^{22}$ Ford, 'Against Cyberspace' (n 10) 155.

${ }^{23}$ Ford, 'Law and Borders' (n 10) 134.

24 Ford, 'Law's Territory' (n 21) 904.

${ }^{25}$ Ford, 'Law's Territory' (n 21) 855-858; Ford, 'The Boundaries of Race' (n 10) 1858. 
To appreciate the point that social practice gives territory a meaning, one only needs to understand the difference between legal presence and physical presence. ${ }^{26}$ A person can be considered domiciled and legally present for the purposes of taxation or voting even though the person is physically present in another country. ${ }^{27}$ An illegal immigrant may not be regarded as resident in a country even though, he or she is physically present there. ${ }^{28}$ Therefore, jurisdiction is a 'governmental technique.'29 It is a skillful or efficient way of carrying out a particular task by government.

Two innovations gave rise to jurisdiction. They are technological and normative. The technological one is cartography which makes it possible to delimit physical territory with searing exactitude, while the normative one is 'the ideology of rational, humanist government.'30 A rational, humanist government is concerned with solving the problems of its people and employs a tool that will serve this purpose. It is not sentimental about achieving its goal for its people, rather it is practical. For example, governance in Siam was initially based on status. At that time, government relied on labor of slaves and serfs. However, in the latter part of the nineteenth century, status was replaced with territory. The reason was that the government needed to guard against internal threats and collect revenue. ${ }^{31}$ Eventually, the combination of human body and geographical territory, that is, 'geo-body', was brought into

${ }^{26}$ Ford, 'Law's Territory' (n 21) 905; Ford, 'Against Cyberspace' (n 10) 154; Ford, 'Law and Borders' (n 10) 129 .

27 Ibid.

28 Ibid.

29 Ford, 'Law's Territory' (n 21) 920; Ford, 'Law and Borders' (n 10) 132; Holt Civic Club v City of Tuscaloosa, 439 US 60, 72 (1978).

30 Ford, 'Law and Borders' (n 10) 134.

${ }^{31}$ Ibid 134-137. 
existence and Siam, which initially did not attach much importance to territory, became the land of the Thai, Thailand. $3^{2}$

In the same vein, territory did not have any significant meaning in Europe until the fifteenth century. At that time, kings did not rule over territories, they ruled people who were united by kinship, common interest, and customs. Territory became relevant later because feudalism was strengthened by cartography. 33 Therefore, while people tend to think that territorial jurisdiction has always been with humans, this is not the case. In fact, territorial jurisdiction is recent. Because people have been so used to it, they cannot imagine that government can be organized differently. ${ }^{34}$ Territorial jurisdiction was invented in the same way tungsten filament was and there is no basis to think it is ageless, inherent in nature or indispensable. 35

\section{PART 2. THE PSYCHOLOGY OF JUDGING}

The process of deciding cases is an intriguing one and has attracted the attention of legal philosophers with respect to its workings. ${ }^{36}$ Thus, Benjamin Cardozo sought to explain it. In so doing, he first raised a number of thought-provoking questions:

What is it that I do when I decide a case? To what sources of information do I appeal for guidance? In what proportions do I permit them to contribute to the result? In what proportions ought they to contribute? If a precedent is applicable, when do I refuse to follow it? If no precedent is applicable, how do I reach the rule that will make a precedent for the

$3^{2}$ Ford, 'Law's Territory' (n 21) 872.

33 Ibid 872-875.

34 Ibid 843 .

35 Ibid 929.

${ }_{36}$ Cardozo (n 11) 9. 
future? If I am seeking logical consistency, the symmetry of the legal structure, how far shall I seek it? At what point shall the quest be halted by some discrepant culture, by some consideration of the social welfare, by my own or the common standards of justice or morals?37

After he raised the questions, he sought to explain the process through which cases are decided by providing answers to those questions:

Into that strange compound which is brewed daily in the caldron of the courts, all these ingredients enter in varying proportions. I am not concerned to inquire whether judges ought to be allowed to brew such a compound at all. I take judge-made law as one of the existing realities of life. There, before us, is the brew. Not a judge on the bench but has a hand in the making. The elements have not come together by chance. Some principle, however unavowed and inarticulate and subconscious, has regulated the infusion... There is in each of us a stream of tendency...which gives coherence and direction to thought and action. Judges cannot escape that current any more than other mortals. All their lives, forces which they do not recognize and cannot name, have been tugging at them-inherited instincts, traditional beliefs, acquired convictions; and the resultant is an outlook on life...In this mental background every problem finds its setting. We may try to see things as objectively as we please. Nonetheless, we can never see them with any eyes except our own. ${ }^{8}$

In his explanation, Benjamin Cardozo acknowledged the existence of some deep-seated influences underneath the actions of judges while judging. These influences are in the form of

37 Ibid 10.

${ }^{8}$ Ibid 10-13. 
preconceived sentiments, deep convictions or values from which perspectives, issues are analyzed. However, these influences are not synonymous with 'favor or prejudice in any sordid or vulgar or evil sense.'39 While reflecting on the nature of judicial process, Benjamin Cardozo envisaged a time when his findings borne of reflections would have scientific backing to determine their veracity.$^{40}$ Indeed, some of his findings have been confirmed through scientific studies. ${ }^{41}$ Variation in sentencing practice has been found not to be completely free of bias against ethnic minorities. ${ }^{42}$ Similarly, it has been openly acknowledged that judges, at least at the appellate level, can be classified as conservative or liberal. ${ }^{43}$

Oliver Wendell Holmes, like Benjamin Cardozo also ruminated on the nature of judicial process. He observed that:

The training of lawyers is a training in logic. The processes of analogy, discrimination, and deduction are those in which they are most at home. The language of judicial decision is mainly the language of logic...Behind the logical form lies a judgment as to the relative worth and importance of competing legislative grounds, often an inarticulate and unconscious judgment, it is true, and yet the very root and nerve of the whole proceeding. You can give any conclusion a logical form. You always can imply a condition in a contract. But, why do you imply it? It is because of some belief as to the practice of the community or of a class, or because of some opinion as to policy, or in short, because of some attitude of yours upon a matter not capable of exact quantitative measurement, and therefore not capable of

\footnotetext{
39 Ibid 174.

40 Ibid 13.

${ }^{41}$ Susan U Phillips, Ideology in the Language of Judges: How Judges Practice Law, Politics, and Courtroom Control (Oxford University Press 1998).

42 Ibid xi.

43 Ibid xiii.
} 
founding exact logical conclusions. Such matters really are battlegrounds...where the decision can do no more than embody the preference of a given body in a given time and place. 44

If one considers what Benjamin Cardozo and Oliver Wendell Holmes said on the nature of judicial process, it can be inferred that how judges interpret law and the extent to which they allow a law to bear on a particular issue is a reflection of their view of the world which is an idea of how they think the world should be. While it influences their interpretation of the law, this should not be confused with bias or favor in a contemptible manner. While logic plays a significant role in deciding cases, inferences drawn from legal rules when applied to facts reflect judges' convictions and values.

Having discussed politics of space and psychology of judging, how judges unconsciously play politics of space whenever they are called upon to determine jurisdictional disputes will now be examined.

PART 3. THE POLITICS OF SPACE IN JURISDICTIONAL DISPUTES WITHIN THE CONTEXT OF PSYCHOLOGY OF JUDGING

In examining how judges play politics of space while settling disputes between the central government and the federating units with respect to their sphere of operation, past judicial decisions in the United States and Canada will be examined. These cases are substantially in respect of how the commerce clause in these two countries are interpreted. The commerce clause offers an interesting dimension because it appears broad and tends to accommodate two diametrically opposed views at the same time.

44 Holmes (n 12) 998. 
In Wickard v Filburn, 45 the central government in the United States sought to stabilize the price of wheat by controlling the amount of wheat produced. It then enacted the Agricultural Adjustment Act of 1938 pursuant to Article 1, Section 8 of the Commerce Clause in the American Constitution which empowered the US Congress to 'regulate commerce with foreign Nations, and among the several States, and with the Indian Tribes.' Roscoe Filburn, a farmer in Dayton, Ohio, produced wheat in excess of what he was permitted to produce under the Agricultural Adjustment Act of 1938, and was fined. He then challenged the imposition of the fine. The issue before the United States Supreme Court was the constitutionality of Agricultural Adjustment Act of 1938 enacted pursuant to the Commerce Clause of the United States Constitution. If the Act was constitutional, the fine imposed on Filburn would be sustained. But the constitutionality of the Act rested on the construction of the Commerce Clause. Filburn maintained that the wheat he produced in excess of what he was permitted was produced for his own home consumption and that what he did could not be regarded as commerce let alone an interstate one. The Supreme Court disagreed. ${ }^{46}$ The Court held that it did not matter how Filburn's action would be characterized but that it was the effect of his actions that would be the deciding factor. ${ }^{47}$ The Court reasoned that if all farmers decided to produce for their own consumption, the amount of wheat produced would be affected and it would in turn affect the price. $4^{8}$ Thus, the fine imposed was sustained.

If one considers Wickard from the perspective of Henri Lefebvre's theory, the judges who delivered the judgment reconstructed space. With their decision, the whole of the United States was made the sphere of operation for the US Congress. Each of the territories of the federating

\footnotetext{
45317 US 111 (1942).

46 Ibid per Robert H. Jackson who was unanimously joined in his decision.

47 Ibid 119-120, 124-125.

48 Ibid 128-129.
} 
states was conflated with one another to form a single unit. The judgment reinforced centralization as social practice. Since social practice is people's way of life, the judgment and its centralizing content is also a part of people's way of life and constitute social practice. The judges placed emphasis on the effect of Filburn's action, but by doing this, they chose what was favorable to centralization, which was their ideological bias. Filburn's argument that he intended the wheat for his home consumption was equally sustainable within the meaning of the Commerce Clause. But it was downplayed. Thus, it can be argued that what one emphasizes and de-emphasizes is a product of one's ideological leaning and it played out in this instance. However, the judges were not biased in any derogatory sense.

In United States $v$ Lopez,49 the United States Supreme Court was confronted with the constitutionality of the Gun-Free School Zones Act of 1990. The Act was part of the Crime Control Act of 1990 and it prohibited the possession of handguns within 1000 feet (305 meters) of a school. In the majority decision (5-4), the Court held that Lopez's possession of the gun could not be validly prohibited under the Commerce Clause because it could not be characterized as an economic activity.$^{50}$ In the dissenting opinions, it was argued that Lopez's possession of the gun could be validly prohibited under the Commerce Clause because gun violence could have significant effect on interstate commerce by impairing learning environment. $5^{1}$

In this case, the outcome of the decision of the majority was that space was constructed by dividing the territory of the United States into several distinct spaces, each occupied by a federating state. With respect to the minority, the implication of their opinion was the

49514 US 549 (1995).

$5^{\circ}$ Ibid per Chief Justice William Rehnquist. Justice Clarence Thomas wrote a separate concurring judgment.

${ }^{51}$ Ibid per Justices Stephen Breyer, David Souter, John P. Stevens and Ruth Bader Ginsburg. 
conflation of each of the territories of the federating units. The majority judgment reinforced decentralization as social practice by declaring the US Congress incompetent. When the majority placed emphasis on characterization, it was because it was favorable to their ideological leaning which was decentralization. The judges in the minority were not in any way different from those of the majority. When they emphasized effect, it was because it was favorable to centralization as their ideological leaning. Again, none of the judges was biased in a pejorative sense.

In United States v Morrison, $5^{2}$ the issue before the United States Supreme Court was the constitutionality of the Violence against Women Act of 1994 enacted by the US Congress pursuant to the Commerce Clause of the American Constitution. The Act empowered victims of gender-motivated violence to sue their attackers in federal court. The majority held that the subject of the statute could not be characterized as economic even if it could have economic consequences and that the US Congress could not have validly legislated on it pursuant to the Commerce Clause.53 The majority stated that the US Congress, could not without limit, extend its powers and truncate central/local divide in federalism. However, the minority stated that the Act was within the competence of the US Congress within the meaning of the Commerce Clause and that its effect on commerce was sufficient to justify its competence. ${ }^{54}$ They stated further that if the Commerce Clause would negative federalism, it was not the business of the court to concern itself with it and that the political organ should be the one to amend the US Constitution along the lines of its preference.

\footnotetext{
$5^{2} 529$ US 598 (2000).
}

53 Ibid per Chief Justice William Rehnquist and Justices Sandra Day O'Connor, Antonin Scalia, Anthony Kennedy and Clarence Thomas. Justice Clarence Thomas delivered a concurring judgment. 54 Ibid per Justices David Souter, John P. Stevens, Ruth Bader Ginsburg and Stephen Breyer. 
In Morrison, the politics of space played out as it was in Lopez. The issue was between characterization and effect. The majority who supported decentralization placed emphasis on characterization and concluded that violence against women could not be characterized as an economic issue even if some economic consequences would result. The fact that some economic consequence would be occasioned was an irrelevant consideration. When the judges in the majority placed emphasis on characterization, it was to give their ideological position, a logical conclusion. As noted by Oliver Wendell Holmes, nearly anything could be given a logical conclusion, it all depends on the premise which can be infused with one's preference. ${ }^{55}$ On the other hand, the minority that supported centralization placed emphasis on the effect. The fact that violence against women could have some economic effect, even if it had not in actual fact, was sufficient. It was irrelevant that the issue of violence could not be characterized as an economic issue. The minority tended to give their judgment a semblance of neutrality by stating that it was not the business of the court to concern itself with federalism if the Commerce Clause would negative it and that the political organ could choose to intervene if it so felt. But the consequence of their neutrality was the reconstruction of space in favor of centralization, and the conflation of each territory of the constituent units with one another to form a single unit. Thus, in their neutrality is bias. With the judgment which qualifies as law, the majority succeeded in calibrating the United States territory into several units and reinforced decentralization as social practice. Also, as it was in the previous cases, none of the judges was biased in a manner unbecoming of a judge.

In Gonzalez v Raich,56 the State of California enacted Compassionate Use Act of 1996. The Act permitted the use of marijuana for medicinal purpose. The Act was enacted by referendum

\footnotetext{
55 Holmes (n 12) 998.

${ }^{56} 545$ US 1 (2005).
} 
and could be seen as a direct reflection of what the people of California wanted. ${ }^{57}$ Angel Raich relied on marijuana locally produced and supplied by her care givers. Diane Monson planted marijuana in California but her plants were destroyed by agents of the federal Drug Enforcement Administration ostensibly acting under the federal Controlled Substances Act (CSA) 1970 which declared the plants illegal..$^{8}$ Both Raich and Monson filed an action against the federal government claiming for an injunctive relief to prevent the government from interfering with their right to plant and use marijuana and a declaratory relief that the Controlled Substances Act was unconstitutional as applied to their conduct. ${ }^{59}$ Raich claimed that she might die of excruciating pain if she was not allowed to take marijuana and that she could not be treated by conventional medical prescriptions. This claim was supported by her physician. ${ }^{60}$ Monson also described the severity of her own afflictions and how conventional medications could not avail her. ${ }^{61}$ The government claimed that the Controlled Substances Act did not recognize the use of marijuana for medical purposes and that growing marijuana locally for medical purposes affects interstate market of marijuana. ${ }^{62}$ The Supreme Court held by a majority decision that the federal government could prohibit the use of marijuana in the state because its use in the state had effect on its demand and supply in the national market. ${ }^{63}$ However, the minority stated that growing marijuana in one's home for one's own medicinal consumption could not be characterized as something of interstate interest and that federalism

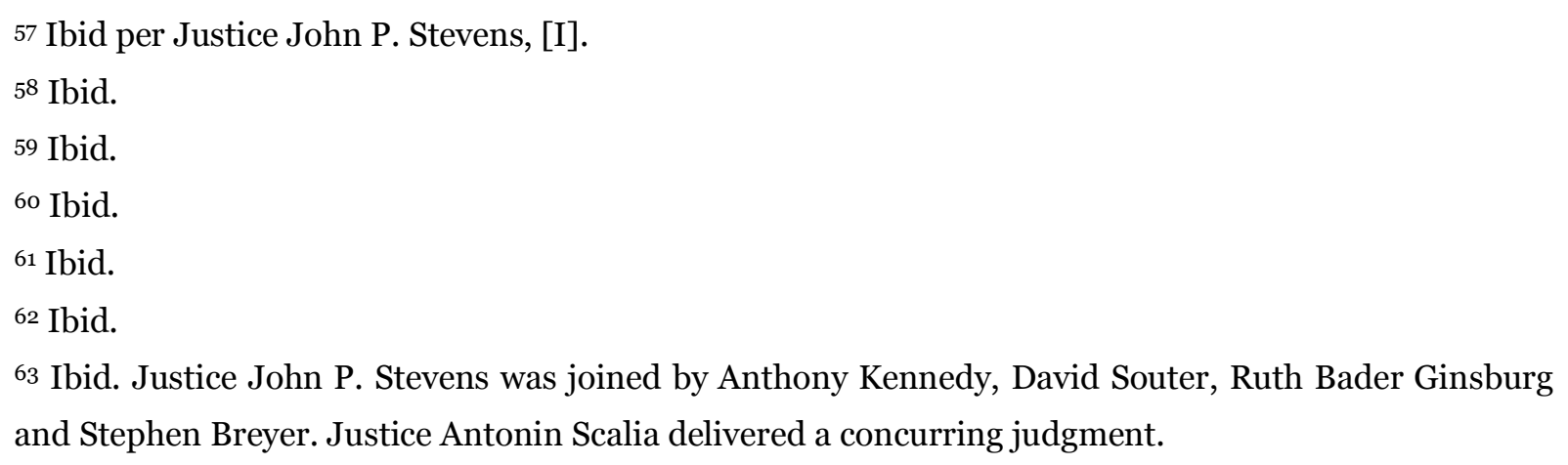


must allow experimentation at local level. ${ }^{64}$ It was stated further that marijuana that was never bought or sold, that never crossed state lines, and which had had no demonstrable effect on national market for marijuana was not commerce among several states and that there must be a limit to the extent of federal power under the commerce clause. ${ }^{65}$

As it was in Morrison and Lopez, so it was in Gonzalez. The conflict was also between characterization and effect, that is, characterizing the activity as economic or the effect that it has on economic activities. Thus, characterization led to decentralization while effect led to centralization. The majority in Gonzalez downplayed the health of Raich and Monson whereas the minority emphasized it. But why one had to be downplayed against the other was nothing but politics of space and the consequence is space construction. With effect, the territories of the federating units were conflated into a single unit; and Raich and Monson together with others in a similar situation fell within the control of the US Congress that did not appear to be sympathetic to their plight. In fact, Richard Ford's analysis that territory is meaningless and that it is social practice that gives it meaning finds reflection in the majority judgment. Thus, Raich and Monson were in the territory of California but the judgment took them away from the sympathy of their community and placed them in the hand of unsympathetic US Congress even though they remain on the same physical territory. With characterization, the minority delimited the territorial space of the United States into several units and shielded Raich and Monson from the jurisdiction of the US Congress.

In the events leading up to the National Federation of Independent Business v Sebelius, ${ }^{66}$ the US Congress enacted the Patient Protection and Affordable Care Act. The Act increased the

\footnotetext{
64 Ibid per Justice Sandra Day O’Connor joined by Chief Justice William Rehnquist. Justice Clarence Thomas delivered a separate dissenting judgment.

65 Ibid per Justice Clarence Thomas.

${ }^{66} 567$ US 519 (2012).
} 
number of Americans covered by health insurance and decreased the cost of health insurance. It required most Americans to maintain 'minimum essential' health insurance coverage which could be through their employer or the government. Where a person could not be insured by their employer or government and the person was not exempted, the person would have to purchase insurance coverage from a private company. If the person refuses to purchase, the person would have to pay a 'penalty' in form of tax. Also, the Act expanded Medicaid program and increased the number of individuals the states must cover. The Act increased federal funding to states to cover the cost of the expansion. However, where a state refuses to comply, it might lose not only the new federal funding but the previous funding from the Federal Government. Twenty-six states, several individuals, and the National Federation of Independent Business challenged the competence of the US Congress to impose penalty for failure to purchase insurance coverage and expand Medicaid program.

In an opinion written by Chief Justice Roberts, the majority held that the Congress could not force people to purchase insurance coverage under the Commerce Clause because failure to purchase could not be construed as an economic activity and that there must be an economic activity on ground before it could be regulated by the Congress. He emphasized the point that the Commerce Clause was already expansive in its operation and to construe otherwise would further expand its reach. The majority also held that the Congress could not rely on Necessary and Proper Clause to force people to purchase but that under the taxing powers of the US Congress, the US Congress could impose penalty in form of a tax to force people to purchase insurance. With respect to the expansion of the Medicaid, Chief Justice Roberts severed the new expansion from the previous one and held that denying the states previous funding under the spending clause for failure to comply was coercive and could not be sustained in light of 
the federal nature of the American Constitution. Chief Justice Roberts was joined by Justice Breyer and Justice Kagan on the issue of expansion.

Justice Ginsburg joined by Justice Sotomayor, Justice Breyer and Justice Kagan held that people could be forced to purchase insurance policy under the Commerce Clause and that the distinction between economic activity and inactivity was unduly technical going by the fact that all Americans would have a reason to need health services at one time or the other in their lifetime. Justice Ginsburg also added that the cost of insurance would be affected across the states when those who were required to purchase refuse to purchase. Thus, the effect of failure to purchase was sufficient for congressional intervention. On the expansion of the Medicaid program, Justice Ginsburg stated that what was expanded was the existing Medicaid and that there was no basis to sever the previous funding from the current one. Justice Scalia joined by Justice Kennedy, Justice Thomas and Justice Alito dissented. They held that apart from the fact that the US Congress could not rely on the Commerce Clause and Necessary and Proper Clause, it could also not rely on its taxing powers because what it did was in substance not an imposition of tax but penalty. They also held that the expansion of the Medicaid and the power to withhold previous funding was coercive.

Both the lead judgment and the concurring judgment favored centralization albeit in different degrees. Thus, Chief Justice Roberts would sustain forcing people to purchase insurance policy on taxing powers but would prevent denying funding to states when they refuse to expand their Medicaid programme. Since individuals cut across the states, the territorial reach of the US Congress is expanded although states could not be 'coerced'. Justice Ginsburg would extend the territorial reach of congressional power to the extent that it could go as she did not see coercion in any form. The dissenting Justices would not permit further 
extension beyond what Congress had already acquired. While none of them is biased in any derogatory sense, they all played politics of space.

In Reference Re Securities Act, ${ }^{67}$ the Canadian government sought to establish a single national securities regulator and published in 2010 a draft Canadian Securities Act. The Governor-in Council sought the advisory opinion of the Supreme Court of Canada in respect of the constitutionality of the proposed Act. The question posed was whether the proposed Canadian Securities Act fell within the legislative authority of the Parliament of Canada. In issue was whether the securities industry could be validly regulated by the Canadian government in the exercise of its trade and commerce power under section 91(2) of the Constitution Act 1867. The Supreme Court of Canada declared the proposed Act invalid under the trade and commerce power. ${ }^{68}$ The Court noted that while management of systemic risk and national data collection appeared to be related to the general trade and commerce power, ${ }^{69}$ other aspects of the Act regulating contracts for securities within the provinces including all aspects of public protection and professional competences fell within the competence of provinces. ${ }^{70}$ Although, the economic importance and pervasive character of the securities market supported federal intervention, this was not sufficient to trump the fact that securities were to be essentially regulated at the provincial level. ${ }^{71}$ The Court further stated that the federal scheme did not accidentally intrude on provincial powers in this proposed Act, but the Act was ultra vires the federal power ab initio. ${ }^{72}$

672011 SCC 66.

68 Ibid per Beverly McLachlin CJ joined unanimously by Justices Ian Binnie, Louis LeBel, Marie Deschamps, Morris Fish, Rosalie Abella, Louise Charron, Marshall Rothstein and Thomas Cromwell.

69 Ibid [103].

70 Ibid [122].

${ }^{71}$ Ibid [128].

${ }^{2}$ Ibid [129]-[130]. 
In this judgment, there was also politics of space. When the Court stated that the pervasive character of securities market could not trump the fact that securities were essentially within the competence of the provincial governments, the Court was emphasizing characterization. There was no doubt that in Canada, the provinces have always regulated securities market73 and this tended to inform the decision of the Court. However, the Canadian government pointed out that the nature of securities in modern time had been completely changed by technology and that this had made it practically impossible to be regulated by the provinces. This was a persuasive argument that could have justified declaring the proposed Act constitutional for a judge who is favorably disposed to centralization. Similarly, when the Court stated that the issue was not one where the federal scheme accidentally intrudes on provincial powers but one that is ultra vires the federal power ab initio, the Court was emphasizing characterization whereas the nature of what was being characterized had radically changed from what it was. The ideological disposition of the judges towards decentralization informed this position. The consequence of the judgment was a delimitation of the territory of Canada into several units. In this instance as in previous ones, the judges were not biased in any derogatory sense.

In Canada (Attorney-General) v PHS Community Services Society,74 the use of drugs by injection became a crisis in the early 1990s in Vancouver's downtown eastside. HIV/AIDS epidemics and hepatitis $\mathrm{C}$ followed. This led to a declaration of public health emergency. ${ }^{75}$ Research conducted by health authorities showed that a creative approach would be needed to address the situation. The approach was that drug addicts would be allowed to consume drugs

$$
\begin{aligned}
& 73 \text { Ibid [11]-[31]. } \\
& 742011 \text { SCC } 44 . \\
& 75 \text { Ibid [11]. }
\end{aligned}
$$


by injection in a facility duly supervised. ${ }^{6}$ This approach was controversial in North America although there was evidence of its use also in Europe and Australia. ${ }^{77}$ To successfully operate the facility required granting an exemption under the Controlled Drugs and Substances Act (CDSA) which was a federal enactment prohibiting possession and trafficking of drugs. ${ }^{78}$ In 2003, the exemption was granted by the Minister of Health and it was extended temporarily in 2006 and 2007 but the Minister indicated that he was not prepared to grant an exemption anymore.79 In 2008, before the subsisting exemption expired, the claimants filed an action contending that the prohibition of possession and trafficking in drugs under the CDSA violated their right to life and security of persons under the Canadian Charter of Rights. ${ }^{80}$ The Supreme Court of Canada unanimously ${ }^{81}$ held that the Canadian government under its criminal power could criminalize any conduct and that it was immaterial whether the issue of health under the competence of the provinces was affected. However, the Court stated that in the case before it the manner of the exercise of the Minister's discretion was arbitrary and violated the principle of fundamental justice under the Canadian Charter of Rights.

With this judgment, the Court constructed space and successfully carved out the territory in which the facility was operating. There is every reason to suggest that the justices who delivered the judgment were motivated by the noble sentiment of preserving the lives of the drug addicts. Thus, the moral controversy surrounding supervising the use of drugs by injection was downplayed for efficiency of the approach. But if the judges were inclined to

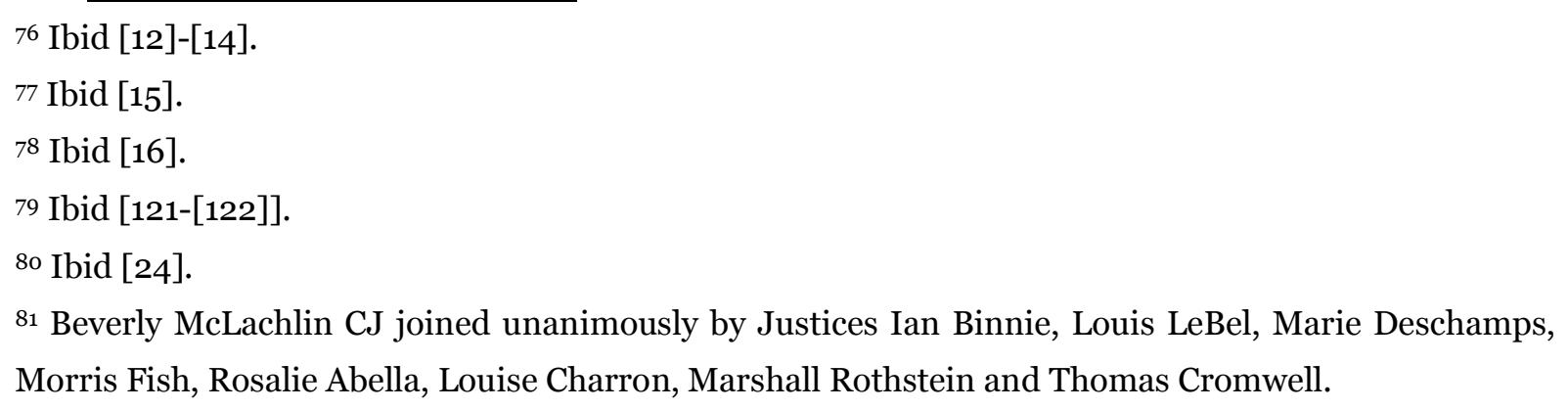


centralization, the US Supreme Court's position in Gonzalez, where federal agents destroyed marijuana planted by one of the claimants in the exercise of its federal power in spite of their health could be maintained. In this respect, the claimants' health would be downplayed while the federal power would be emphasized.

If one considers the reason behind the unanimous judgment, it is somewhat questionable and for a judge inclined to centralization, the questionable reason was sufficient to rule otherwise. By the decision, the issue of discretion has been converted to a duty. What if the discretion was never exercised in the first place? Would the Minister have been forced to exercise it? This was exactly the situation in Gonzalez. The United States government never granted an exemption in the first place. If an entity could exercise a discretion, could that entity not choose to exercise it anymore, if that entity cannot be forced to exercise it in the first place? Suppose that the Canadian government after the decision decides to amend the CDSA and foreclose all exemptions? It was what the Canadian government had in mind when it argued that the Minister's indication not to extend the exemption was not an exercise of discretion and by implication could not be subjected to the test of review, but, the Court held otherwise.

Having discussed the politics of space in resolving jurisdictional disputes, the relevance of Keynesian federalism will now be examined.

\section{PART 4. THE RELEVANCE OF KEYNESIAN FEDERALISM}

Keynesian economics is a metaphor upon which Keynesian federalism rests. ${ }^{82}$ John Maynard Keynes was an economist. He argued that when there was economic depression, the government should have intervened by increasing its spending, and that when there was

\footnotetext{
82 Michael Ilg, 'Keynesian Federalism' (2019) Oxford $U$ Comparative $L$ Forum 4 $<$ ouclf.law.ox.ac.uk>accessed 10 July 2021, text after note 10.
} 
economic boom, the government should have refrained from spending much. He believed that it was only when government intervened that equilibrium in the long run could be achieved. He rejected the classical position that equilibrium would automatically be achieved on its own by the interplay of the forces of demand and supply in the long run. ${ }^{83}$ Keynesian economics exhibits two main features: reactivity and counterbalancing. What this implies is that government would only react to situations of economic boom and recession. Counterbalancing has to do with attaining equilibrium. ${ }^{84}$

When Keynesian economics is adopted as a metaphor for federalism, what it implies is that whenever the economic situation calls for the intervention of the central government because efficiency is paramount, an interpretation favorable to centralization should be adopted. However, after this decision, whenever there is another economic dispute, interpretation favorable to decentralization would be privileged through the doctrine of presumptions. Thus, it would be presumed that an interpretation favorable to decentralization would be adopted unless it is rebutted. ${ }^{85}$ Keynesian federalism will displace the settled principle of judicial precedent, but it would offer equal chances to the forces of centralization and decentralization. While Keynesian federalism applies to disputes of economic nature, it can also be applied to all forms of dispute where constitutional provisions are sufficiently broad to accommodate at the same time the forces of centralization and decentralization. Although the commerce and trade clause in the United States and Canada tends to suggest that the principles of Keynesian federalism can only apply to economic disputes, it can apply to all

83 John Maynard Keynes, The General Theory of Employment, Interest, and Money(Palgrave Macmillan 2018).

$84 \mathrm{Ilg}$ (n 82) text after note 3.

85 Ibid. 
disputes because issues of commerce and trade have gone beyond their traditional meaning to encompass nearly everything.

If Keynesian federalism is adopted, the politics of space would be substantially reduced, and both the supporters of centralization and decentralization would be given equal chances. Of course, it can be argued that the doctrine of presumptions which is supposed to privilege an interpretation over the one previously adopted may also be infused with politics of space. Nonetheless, it can reasonably serve as a hurdle to be crossed and constitutes a device to prevent the supporters of one from continuously having their way over the other.

\section{CONCLUSION}

This study examined judicial interpretation in resolving conflict on jurisdiction between the central government and the federating units. It applied Henri Lefebvre's theory of space, Richard Ford's analysis of jurisdiction, Benjamin Cardozo's and Oliver Wendell Holmes's psychology of judging to judicial interpretation in resolving conflict on jurisdiction between the central government and the federating units. It found that there is tension between the central government and the federating units, manifesting as the tension between the forces of centralization and decentralization and that resolving the tension has been an intractable issue. It also found that this tension finds expression when justices interpret the constitution to resolve questions of jurisdiction between the central government and the federating units as they often play politics of space within the interstices of legal rules without being conscious of their psychological biases. Hence, it is argued that the principles in Keynesian federalism bolstered by the rule of presumption should be adopted. With this, the influence of politics borne of psychological biases can be reduced while both the central government and the 
federating units will have equal chances in terms of balancing the forces of centralization with those of decentralization. 